\title{
Estimating the long-term historic evolution of exposure to flooding of coastal populations
}

\author{
A. J. Stevens ${ }^{1}$, D. Clarke ${ }^{1,3}$, R. J. Nicholls ${ }^{1,3}$, and M. P. Wadey ${ }^{2}$ \\ ${ }^{1}$ Faculty of Engineering and Environment, University of Southampton, University Road, Highfield, \\ Southampton, SO17 1BJ, UK \\ ${ }^{2}$ Ocean and Earth Science, National Oceanography Centre, University of Southampton Waterfront Campus, European Way, \\ Southampton, SO14 3ZH, UK \\ ${ }^{3}$ Tyndall Centre for Climate Change Research, Norwich, UK
}

Correspondence to: A. J. Stevens (andy.stevens@ soton.ac.uk)

Received: 1 December 2014 - Published in Nat. Hazards Earth Syst. Sci. Discuss.: 27 February 2015

Revised: 17 May 2015 - Accepted: 21 May 2015 - Published: 15 June 2015

\begin{abstract}
Coastal managers face the task of assessing and managing flood risk. This requires knowledge of the area of land, the number of people, properties and other infrastructure potentially affected by floods. Such analyses are usually static; i.e. they only consider a snapshot of the current situation. This misses the opportunity to learn about the role of key drivers of historical changes in flood risk, such as development and population rise in the coastal flood plain, as well as sea-level rise.

In this paper, we develop and apply a method to analyse the temporal evolution of residential population exposure to coastal flooding. It uses readily available data in a GIS environment. We examine how population and sea-level change have modified exposure over two centuries in two neighbouring coastal sites: Portsea and Hayling Islands on the UK south coast. The analysis shows that flood exposure changes as a result of increases in population, changes in coastal population density and sea level rise. The results indicate that to date, population change is the dominant driver of the increase in exposure to flooding in the study sites, but climate change may outweigh this in the future. A full analysis of changing flood risk is not possible as data on historic defences and wider vulnerability are not available. Hence, the historic evolution of flood exposure is as close as we can get to a historic evolution of flood risk.

The method is applicable anywhere that suitable floodplain geometry, sea level and population data sets are available and could be widely applied, and will help inform
\end{abstract}

coastal managers of the time evolution in coastal flood drivers.

\section{Introduction}

One tenth of the world's population live in the low elevation coastal zone (Lichter et al., 2011), or are exposed as temporary residents due to coastal tourism and industry (Kron, 2008). More than 200 million people are estimated to be at risk of flooding from extreme sea levels caused by storms (Nicholls, 2010). Hence there is an urgent need for coastal managers to understand coastal flood risk, the drivers of the risk and how the drivers change over time. Drivers of flood risk include population exposed to flooding, frequency of extreme events and the effectiveness of any flood defences and of any other adaptation. All of these drivers can change over time so a full analysis should include an evaluation of how these drivers evolve both historically and into the future (via scenario analysis). While there are many future analyses of flooding, historic analyses are less common, which misses important empirical insights on what has happened.

Flood risk can be assessed in a framework which considers the interacting elements of the SPRC (Source-PathwayReceptor-Consequence) model (Holdgate, 1979) or more recently the "flood system" concept (Evans et al., 2004; Narayan et al., 2014; Sayers et al., 2002). Methods to assess exposure to coastal floods have focused on understanding the sources (e.g. extreme sea levels (Haigh et al., 2010; Batstone 
Table 1. Summary of required data and sources.

\begin{tabular}{ll}
\hline Data & Source \\
\hline $\begin{array}{l}\text { Population size and } \\
\text { distribution }\end{array}$ & $\begin{array}{l}\text { Census data (10 year } \\
\text { time steps) }\end{array}$ \\
\hline Urban/residential extent & $\begin{array}{l}\text { Historic maps digitised in } \\
\text { GIS ( 20 year time steps) }\end{array}$ \\
\hline Flood extent & $\begin{array}{l}\text { Inundation model } \\
\text { (after Wadey et al., 2012) }\end{array}$ \\
\hline
\end{tabular}

et al., 2013) and waves (Wolf et al., 2011; Chini and Stansby, 2012)) or pathways (e.g. simulations of defence failure and inundation via event-based approaches (Wadey et al., 2012, 2013) and flood risk assessment (Gouldby et al., 2008; Dawson et al., 2009)). These studies can include the effects of anticipated sea level rise (SLR) which changes the probability of extreme events (Church et al., 2013; Wahl et al., 2013; Haigh et al., 2011). Coastal flood risk is bound to change in time because sea level is rising (IPCC, 2013) and more people are living closer to the sea (Nicholls, 1995; Small and Nicholls, 2003). However, previous studies have not looked at the detailed historic time evolution of this risk. Population assessments have only been considered in time-aggregated analyses such as Foresight (Evans et al., 2004).

Receptors and consequences have usually been incorporated into risk assessments by evaluations of economic consequences in the form of expected annual damages (PenningRowsell et al., 2005, 2013). Tools to model human responses and risk to life have been demonstrated via agent-based models (e.g. Dawson et al., 2011) and empirical methods (e.g. Jonkman et al., 2008; Wallingford et al., 2006).

In this paper, flood risk is considered as the interplay between the probability of a given event occurring, the people and property exposed to the flood event and the vulnerability of those at risk, as defined in earlier work (e.g. Samuels et al., 2009; Blaikie et al., 1994; Gwilliam et al., 2006; Kron, 2005; Fielding, 2007; UNDRO, 1982; United Nations and Birkmann, 2006; USACE et al., 2011).

Probability is included in the source component of the SPRC and it is commonly expressed as a return period (e.g. this work considers the 1 in 200 year flood event - an event that would be expected to occur, on average, once every 200 years, or more formally have a likelihood of occurrence of 0.5 per cent in a single year). This return period was chosen as it is a typical design standard for coastal defences and so is a critical threshold to assess. Exposure describes the area flooded (pathways of the SPRC) and the people/property within this area (receptors) (Narayan et al., 2014). Vulnerability links the receptors and consequence terms of the SPRC and determines the expected damages for given flood characteristics (e.g. in Fig. 1 a house with a raised floor level is less vulnerable, and thus expected damages would be reduced).

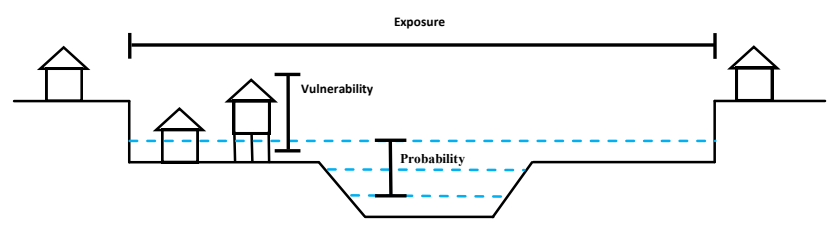

Figure 1. Cross section of a floodplain showing the components of risk.

In this paper, the change in the "exposure" component of flood risk is evaluated (i.e. we do not account for changes in vulnerability or attempt to evaluate the time-evolving cost of damage caused by flooding). We assume that no defences are present. This reflects that we do not have historic data on defences and beach state and these factors are probably not amenable to historic analysis.

In this paper we present a method for assessing the historic exposure of coastal residential populations, and how this has evolved over approximately 200 years (since 1800) for two UK case study sites. The analysis will enable us to determine the key drivers of changes in risk of flooding in the coastal environment. A study site is chosen that represents typical areas of the well-developed UK coast that have already undergone assessments of plausible changes in sea levels and inundation, and has good data sets on population density, coastal floodplain elevations and historic sea levels. Quantifying the number and spatial location of people in the floodplain is vital for effective flood risk management in relation to evacuation planning. It is important to note that the approach in this paper focuses on the population exposure rather than the financial cost of flooding.

The paper is structured into the following sections: Sect. 2, an introduction to the case study region; Sect. 3, methodology including Sect. 3.1, model outline and data sets used, Sect. 3.2, population distribution model, Sect. 3.3, flood inundation model and Sect. 3.4, exposure model (see Appendix A for modelling assumptions); Sect. 4, analysis/results of the exposed population calculations; Sect. 5, discussion and Sect. 6, conclusions and recommendations for future research.

\section{Case study site}

The study site (Fig. 2) is based in the densely populated region of the UK along the Solent estuary which includes the cities of Southampton and Portsmouth. The coastline spans approximately $55 \mathrm{~km}$ "as the crow flies" from Hurst Spit in the west to Selsey Bill in the east but it is heavily indented. The Solent region topography, population and land use is representative of many developed coastal areas, with approximately 25000 properties on land exposed to a 1 in 200 year coastal flood (NFDC, 2010). Portsmouth has the UK's highest population density outside of London, and is a major site where properties are at risk of coastal flooding (RIBA 


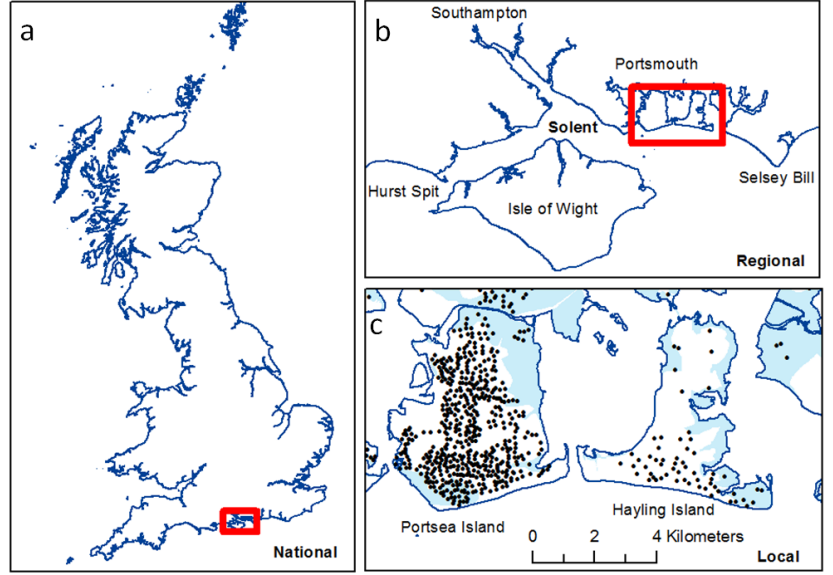

Figure 2. (a) and (b) Location of Portsea and Hayling Islands. (c) Centroid points for population data assigned to the 2011 UK national Census and the Environment Agency's 1 in 200 year indicative floodplain map (IFM, shaded blue) (Centroid points are Crown copyright/database right 2013. An Ordnance Survey/EDINA supplied service. IFM is ${ }^{\circledR}$ Environment Agency copyright and database rights 2015.).

and ICE, 2008). The Solent region faces many of the typical global development pressures on the coast: high population density, a strategic trade location (road and sea transport routes) and tourist/environmental attractions (NFDC, 2010). Some parts of the coastline (notably Portsea Island) have hard engineered sea defences, whereas other sections use softer approaches such as beach nourishment (e.g. Hayling Island). These defences are managed whilst sea levels have been rising, increasing the probability of extreme sea level and flood events (Haigh et al., 2011; Wadey et al., 2013).

There is already a substantial flood history and presentday threat: a study assessing the history of extreme sea levels and media accounts of floods identified 40 flood events in Portsmouth between 1960 and 2005 (Ruocco et al., 2011). On 10 March 2008 a storm surge, high tide and waves in the English channel led to significant coastal flooding in the Solent area (Wadey et al., 2013). The storms and high tides of the 2013-2014 winter caused a number of coastal flood events (Wadey et al., 2015). The study area has been zoned for flood "risk" by the UK Environment Agency for a $1: 200$ year extreme event assuming that no flood defences are present (Fig. 2c). In this study we continue to use the worst case undefended scenario in consistency with current management practices.

This case study tests the developed concept that is transferable to other densely populated coastal regions with appropriate data.

\section{Methodology}

\subsection{Outline and data sets}

In this study we are evaluating the evolution of exposure (as a proxy for risk), measured as the number of people within the indicative undefended coastal floodplain, for a 1 in 200 year flood event, given population change, residential development and sea level rise. A detailed digital elevation model of the floodplain was developed by Wadey et al. (2012). Sea level data are available for the study area for 1960 to 2008 (Haigh et al., 2011). Population data are available from the UK Census for Portsea and Hayling from 1801-2011 at 10 year time steps. Historic maps are available at roughly 20 year time steps $(1870 \mathrm{~s}, 1890 \mathrm{~s}, 1910 \mathrm{~s}$, 1930s, 1960s, 1970s, 1990s and 2010s). From 1870-1990 the maps are at a scale of $1: 10560$. For the 2010s map a scale of $1: 2000$ is available. Data required and sources are summarised in Table 1.

The methodology used in this study is shown in Fig. 3, and details of how the population is located and the flood extent generated are presented in the following subsection. We use known population data from the UK Census, locate the population spatially using historic maps and then identify the number of people exposed to flood risk in the 1 in 200 year floodplain. This process is repeated every 10 years between 1801 and 2011. Exposure is evaluated in a time step of 10 years to match the time step of the census data. Data sets for the physical system (sea levels, tidal curve and land elevations) are combined in a floodplain extent model. This gives the extent of the floodplain at different stages of time (e.g. accounting for changes in sea level, and excluding defences). The changes in historic shoreline position are not accounted for as part of this study.

The socio-economic data sets (population, historic maps) are combined in a population distribution model. This gives the spatial distribution of the population at each time step. For simplicity the extent of the housing development is assumed to be constant between the historic map years, as interpolation of housing development between map dates is difficult and unlikely to provide additional knowledge or understanding.

\subsection{Population distribution model}

\subsubsection{Population count}

Demographic data from the UK Census were used to reconstruct the spatial population distribution at the study site since 1801 at 10 year intervals (Hampshire County Council, 2001; Registrar General for England and Wales, 1971; Office of Population Censuses and Surveys, 1981, 1991; ONS, 2001, 2011). These data were used within the model to identify the coastal population at risk of flooding (Fig. 3). 


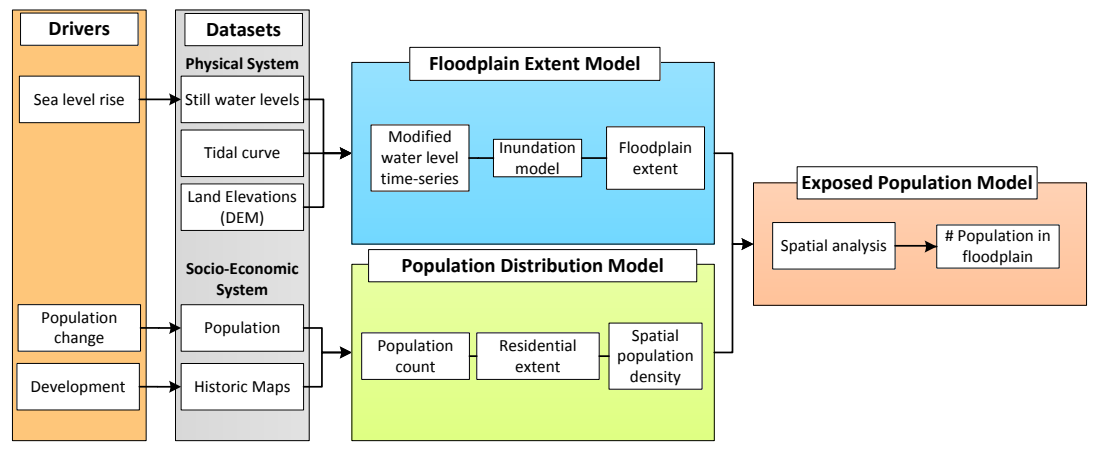

Figure 3. Methodology for evaluating changes to flood exposure.

Prior to 1971 the aggregate population for Portsea and Hayling Islands are used (shown as "non-spatial" data in Fig. 4), because the location of the population was not recorded. Some interpolation was necessary for the Hayling population (see Appendix A).

For census years 1971-2011 spatial census data are available as centroid points. Centroid points (Fig. 2c) represent the population within a census output area. Output areas (OAs) are the lowest geographical level at which census estimates are provided. The output areas are designed to have between 40-125 households, with a minimum population of 100. Census data from the 2001 and 2011 censuses at the output area level were used, (OAs 504 and 522 within Portsea Island, respectively). For 1971, 1981 and 1991, data were extracted at the enumeration district level (312, 314 and 303 EDs, respectively - these censuses pre-date output area levels). Enumeration districts are less well defined, containing between 45-940 people for the 1971 Portsea and Hayling data, for example.

\subsubsection{Historic residential extent}

Maps of Portsea and Hayling Islands between 1870 and 2012 were used to identify the level of development and which areas were populated. Urban areas were digitised to create a residential mask in ARC GIS (geographical information system) and these were used to distribute the population count from the census data into the populated areas and to constrain population to residential areas (see Appendix A).

The digitised residential areas are seen in Fig. 5. Development has increased on both islands between 1870 and 2012 . On Portsea, early residential development (1870s) was centred near the dockyards area to the west of the island with small pockets of residential development elsewhere. The centre and east of the island began to be developed between the 1890 s and 1910 s and by 1930 , the island was largely developed. Major developments since the 1930s include Anchorage park to the north-east of the island (seen in the 1990s map and expanded in the 2010s map), and developments in the Eastney area in the south-east corner of the island (seen from 1960 onwards). Hayling was sparsely developed from the 1870s through to the 1910s. In the 1930s development increased, mostly in the south of the island. As for Portsea, the pattern in the 1930s is similar to that of the modern day, although unlike Portsea, the population has grown more than 4 times larger. For instance, noticeable development did occur in the Eastoke peninsula (south-east corner of the island) seen in the 1960s through to the 2010s map. Portsea Island remains more developed than Hayling throughout the record.

\subsubsection{Spatial population density}

The Census data provided a population count and a centroid point to locate the population in each output area (OA) or enumeration district (ED) (see Fig. 2c). Surface Builder $^{\mathrm{TM}}$ was used to distribute the population spatially (Martin, 1989). This model creates a raster grid with population density in each cell calculated as a function of the distance from each population centroid (see Fig. $6 a, b$ and Appendix A). A raster grid is used as it offers ease of integration with other data sources (e.g. the raster flood maps) (Martin et al., 2011). Complications arose because census areas have changed over time (i.e. are different for each census) and the different geographies between censuses make longitudinal studies problematic (Langford, 2007; Martin et al., 2002). A solution is to use interpolation techniques to transform the population data to a common set of zones (Langford, 2007). For small spatial areas, such as output areas and enumeration districts, remodelling of the data to an underlying surface-based representation may prove the only alternative (Martin et al., 2002). In this study, the census population centroid data were aggregated to raster grid cells of size $50 \mathrm{~m}$ by $50 \mathrm{~m}$ using the SurfaceBuilder ${ }^{\mathrm{TM}}$ program. This grid-based method provides a consistent method of assessing the relationship between social vulnerability and exposure to flooding, as opposed to simpler methods based on census output areas (Martin, 1989; Thrush et al., 2005).

\subsection{Floodplain extent model}

As already noted, sea defences are excluded due to lack of data. An analysis of the effectiveness of coastal flood de- 

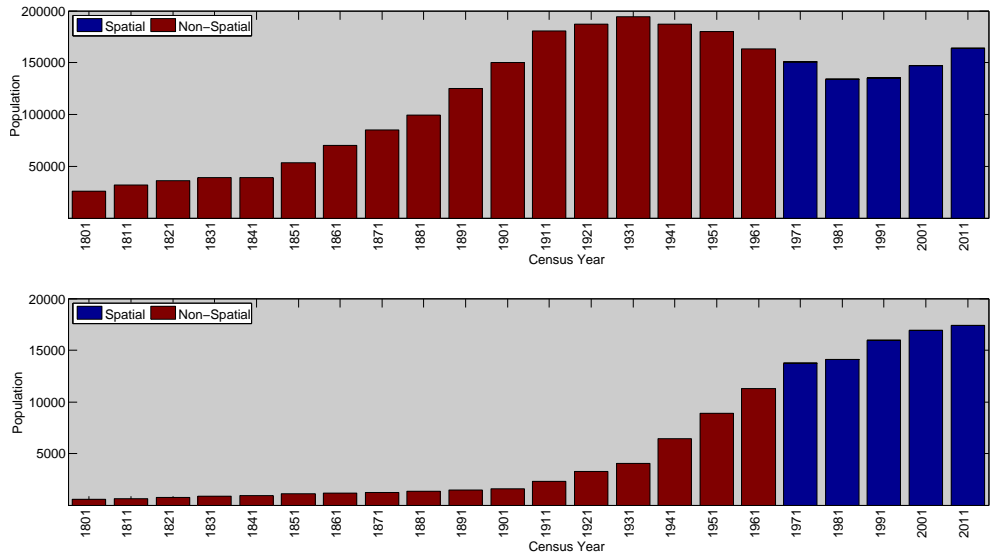

Figure 4. Population time series and source (spatial or non-spatial) for Portsea (above) and Hayling (below).

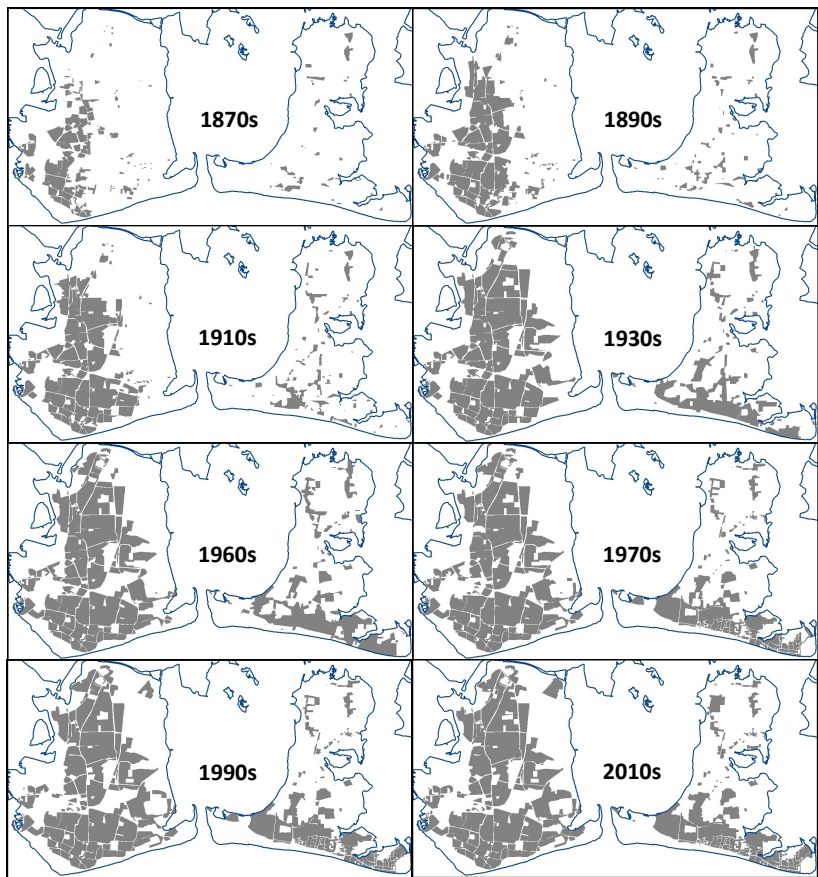

Figure 5. Digitised residential areas in Portsea Island (left island) and Hayling Island (right island). Maps sourced from Digimap $^{\circledR}$ Crown Copyright and Landmark Information Group Limited (2014). All rights reserved. (See Appendix A for comprehensive list of maps used.)

fences is beyond the scope of this paper. The lack of historic data on flood defences makes a temporal study of risk evolution including defences time unfeasible. Our aim is to assess the worst case scenario.

To determine the floodplain extent, we used a combined hydraulic model (LISFLOOD FP) (Bates et al., 2010) and digital elevation model (DEM) (Wadey et al., 2012) for a range of flood simulations by return period assuming no sea defences. LISFLOOD FP is an inertial formulation of the shallow water equations (Bates et al., 2010). It has been used to simulate coastal flood events (Smith et al., 2012; Quinn et al., 2014), including within the Solent (Wadey et al., 2012) where the model has been validated (Wadey et al., 2013). Floodplain flows are treated using a "storage cell" approach and implemented for a raster grid to allow an approximation to a two-dimensional (2-D) movement of the flood wave. A continuity equation is solved linking flow into a cell and its change in volume, and a momentum equation for each direction where flow between cells is calculated. With good quality topographic data, this model can produce similar results to full 2-D formulations of the shallow water equations (for sub-critical gradually varied flows only). The model is run for a single tidal cycle.

This model has been shown to identify properties exposed to flooding in the Portsmouth case study with a vertical accuracy of approximately $\pm 10 \mathrm{~cm}$. The model application by Wadey et al. (2012) was modified in this application for historic simulations of flooding by adjusting the still water level boundary condition. Sea level rise was based on the estimates of Haigh et al. (2011) at Portsmouth from 1960 to 2008 and extrapolated back to $1801\left(1.21 \mathrm{~mm} \mathrm{yr}^{-1} \pm 1\right.$ s.e. $)$.

\subsection{Exposure model (number of people at risk)}

The population layer and flood extent layer are combined to determine the exposed population in the floodplain (Fig. 6). The exposed population in each grid cell is summed to give a total exposed population for that time step. The process was repeated for each census year to assess the evolution of exposure of the coastal population.

\section{Results: changes in population exposed to flooding and its drivers}

The temporal evolution of exposure in Portsea and Hayling are shown in Figs. 7 and 8. The error bars show the variabil- 


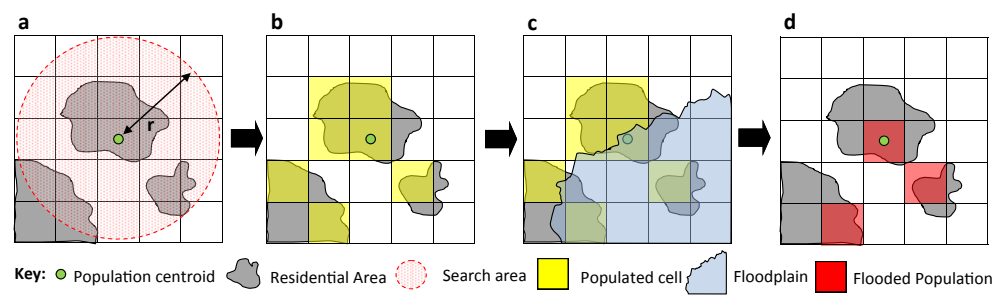

Figure 6. Method to calculate exposed population: (a, b) population is spread from centroid points to a raster grid according to specified search area (see Appendix A), (c) floodplain is overlain and (d) exposed population calculated.

ity in calculated exposure due to uncertainty in the estimates of sea level, population size and distribution (for a breakdown of the uncertainty, see "Sources of uncertainty" in the Appendix). Three rates of sea level rise were used; the mean value for the Portsmouth tide gauge of $1.22 \mathrm{~mm} \mathrm{yr}^{-1}$ (Haigh et al., 2011), and \pm one standard deviation of this value (0.94 and $1.48 \mathrm{~mm} \mathrm{yr}^{-1}$, respectively).

Between 1801 and 2011, the exposed population in Portsea has increased from approximately 1500 people in 1801 to 19800 in 2011 . This represents a greater than 10-fold increase in exposure. Figure 7 shows the temporal evolution; there is a slow rise $1800-1850$, a faster rise $1850-1930$. Exposure then levels off and falls slightly 1940-1970, followed by a further rise 1980-2011. The curve follows the same pattern as the island's total population (Fig. 4). In Hayling there was only a very small population ( $<100$ people) exposed to flooding prior to 1921 and this result is consistent across all sea level rates applied (Fig. 8). From 1921 to 2011 there is an almost 15-fold increase in population exposed to flooding over this period - rising from 120 in 1921 to 1759 in 2011. There are two periods with significant increases in exposure: 1951-1961 and 1971-1981.

To determine the relative importance of sea-level rise and population change as the drivers of flood risk, the exposed populations are re-calculated for two scenarios:

i. sea levels do not change from the extrapolated 1801 level, and population rises;

ii. population in 1801 remains static and sea level rises at the mean rate of $1.22 \mathrm{~mm} \mathrm{yr}^{-1}$.

The results are shown in Fig. 9. The differences between the two curves in each plot indicate the relative contribution to exposure caused by sea level rise and population change. For Portsea, sea level rise between 1801 and 2011 results in an increase in flood exposure to the 1801 population from 2200 to 4000 (i.e. +1800 people, $82 \%$ ), whereas population change over the same period with a static 1801 sea level accounts for +7600 people exposed to flooding (i.e. 2200 9800, $345 \%)$. In Hayling, the equivalent figures are 50 to 50 $(+0$, i.e. no change in exposure due to sea level), but for population change the exposure rises from 50 people in 1801 to 1080 people in 2011 (i.e. +1030 people, $2060 \%$ ).
This demonstrates that population change has been a more important driver of flood risk than sea level rise in both Portsea and Hayling. Indeed at Portsea, population change is 5 times more important in changing flood risk over this period, which in Hayling, in relative terms, has been even more dominant, even though absolute figures are lower. This analysis was repeated for a range of return period water levels including 1 in 1,1 in 5, 1 in 10,1 in 50, 1 in 100 and 1 in 1000 year levels. All of the results show the same trend (albeit for Hayling; there is no exposure for the low return period storms): only the 1 in 200 year results were included in the paper to provide a succinct analysis.

This analysis used the mean change in estimated sea level; there is some uncertainty in the actual sea levels as shown in the error bars in Figs. 7 and 8. This uncertainty may account for a variation in calculated exposure of up to 1000 people in 1981 . There is no easy way to assess the accuracy of the population data, but the data are the best available and it is a legal requirement for all UK residents to register in the Census.

\section{Discussion: overview and applicability to other sites}

This research builds upon that of Foresight (Evans et al., 2004) and Smith (2015) with its strength being in its transferability to other sites. The methodology described here could be applied to any coastal site where adequate spatial data sets (land use, elevations, population) and sea level data are available.

A national analysis of flood risk is possible using this approach, taking advantage of the modern day data collection systems available in many countries. To demonstrate this, a snapshot national analysis was carried out for the present day flood exposure in England and Wales. We used the present day Environment Agency Indicative floodplain map for both river and coastal flooding plus Census data for 2011. There are some limitations in this approach, for example the floodplain map includes both fluvial and marine flood extents. The algorithm took less than $1 \mathrm{~h}$ to run. The calculated exposure to the 1 in 200 year flood event (without sea defences) was 4.8 million people, which is within $10 \%$ of the figure of 5.2 million quoted by the National Flood Forum (NFF, 2015). This quick analysis gives credence to the methodology, how- 


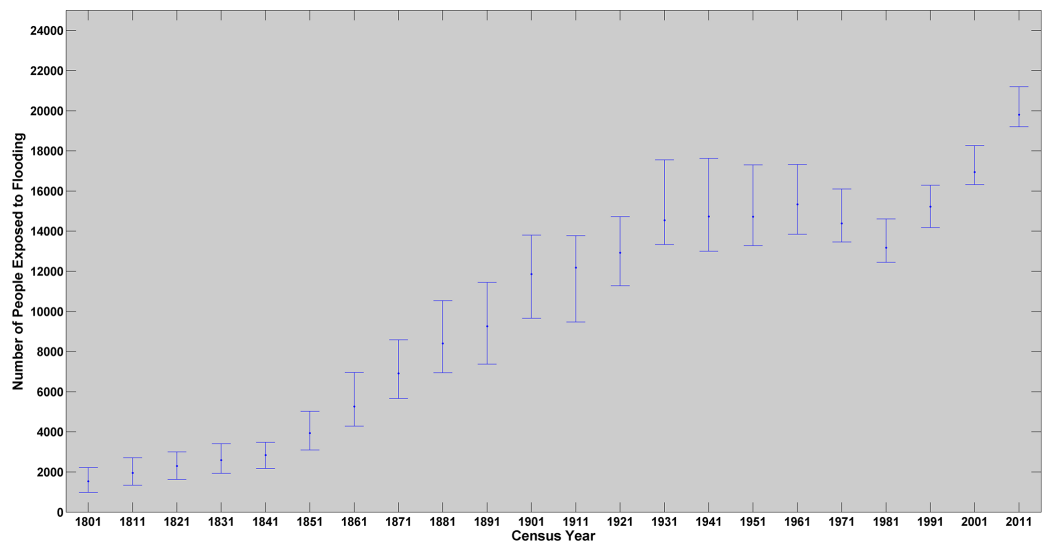

Figure 7. Estimated number of people exposed to flooding in Portsea ( 1 in 200 year recurrence interval, no defences). Error bars represent uncertainty in estimated rate of sea level change, population distribution and population size.

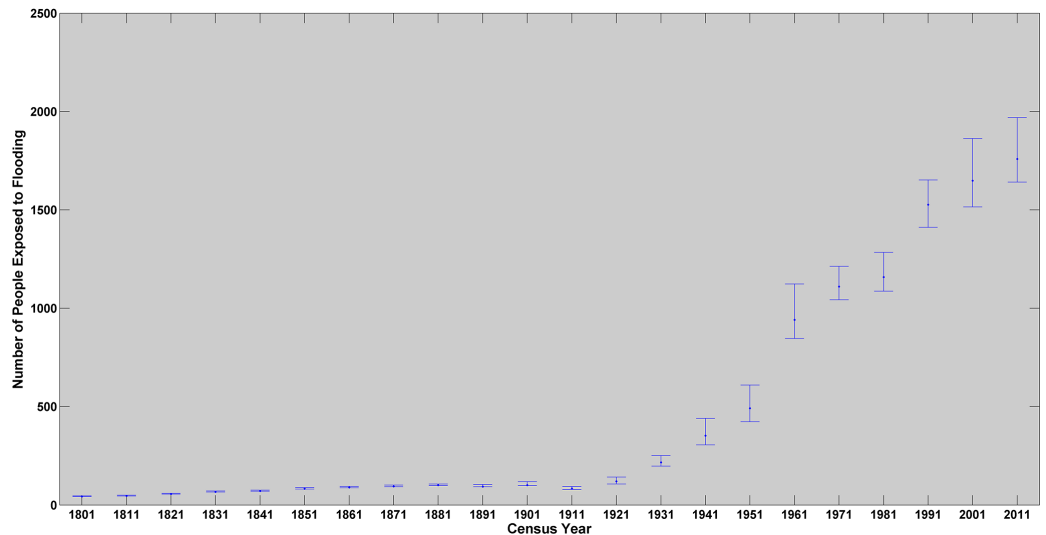

Figure 8. Estimated number of people exposed to flooding in Hayling ( 1 in 200 year recurrence interval, no defences). Error bars represent uncertainty in estimated rate of sea level change, population distribution and population size.

ever, for a full national scale analysis, a more detailed population data set and DEM model would be necessary. To reduce data processing times, analysis could be restricted to only those areas known to be at risk of flooding and it is estimated that a national scale study could be completed in a few months.

For an historical analysis users would need access to population data and indicative floodplain maps at regular intervals. The 10 year time step used in this study was chosen on the basis of the UK Census timings and some interpolation was necessary between the spatial data obtained from maps published at irregular time steps. However, the large time step (10 years) may hide changes in coastal population over shorter timescales because urban development can be rapid and significant areas of new coastal settlements can be constructed in less than 5 years This highlights the need for regular high quality data collection on both physical variables (land elevations, sea levels) and socio-economic variables (population size and density, residential extent). The methodology can be developed to look explicitly at attributing flood risk to the underlying drivers.

Applying the methodology to different case studies will test whether the attribution of flood risk is consistent across a nation or whether regional differences exist. Over the last 200 years, population has increased across the UK, leading to increased encroachment of development and a higher population density upon floodplains so we would expect a similar pattern to that seen in the present case study. Only in lowlying areas where development/population rise has remained static would observed sea level rise have played a more significant role than that of population change. We suggest that this is more likely to be the case in the future as cities such as Portsmouth reach "saturation point" in their development. The existence of exceptions could be tested by repeating the method across the whole country; we propose this as necessary future work.

The evolution of the effectiveness of flood defences is an area for further study as when combined with exposure, it allows estimate of changing flood risk. However this presents 

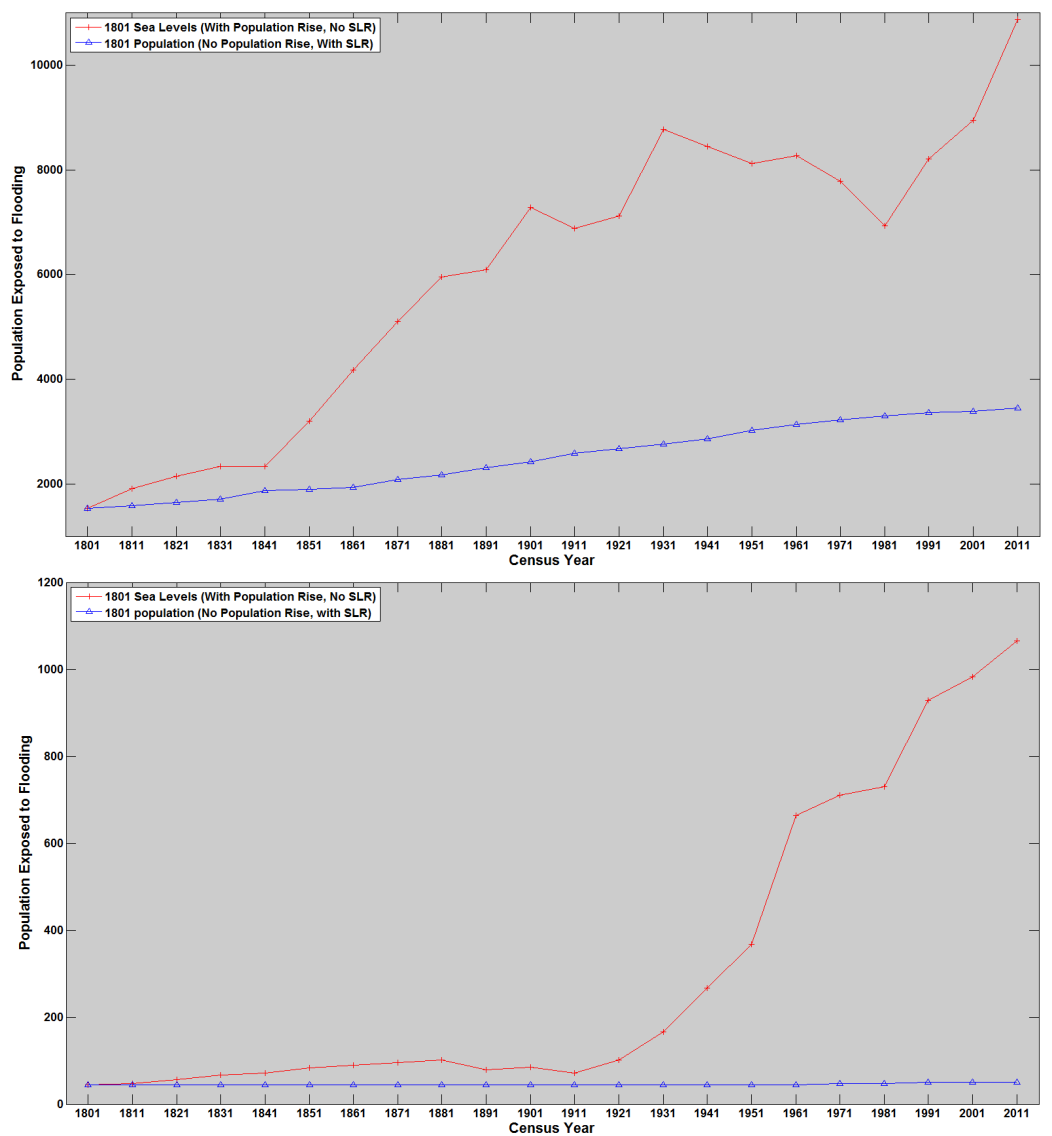

Figure 9. Estimated number of people exposed to flooding (1 in 200 year recurrence interval, no defences) in Portsea (above) and Hayling (below) for no change in sea levels since 1801 (red line) and no change in population since 1801 (blue line).

significant challenges for historical analyses, for example, we found that information on flood defences at Portsea before 1990 is poorly recorded. This is likely to be the general case and hence while we may estimate historic exposure back to 1800 , we cannot similarly estimate flood risk. This emphasises the importance of documenting defences and vulnerability characteristics over time, such as seen in the UK's Strategic Regional Coastal Monitoring Programme (e.g. see http://www.channelcoast.org/).

\section{Conclusions}

This paper has identified and filled a gap in our knowledge of the drivers of risk of coastal flooding, and how this exposure has developed over time. This has implications for the current assessment of coastal flood events, and also for future planning decisions.

In the Solent case study, population change has been shown to be the most significant driver of flood exposure from 1801 to the present time. Observed sea-level rise has a lesser but still significant effect on flood exposure estimates, especially over long timescales (100+ years). The rate of sea level rise is expected to increase, and rising sea levels are likely to have a larger effect on exposure in the future. Furthermore, for small island communities, such as Portsea and Hayling, the area available for development may become a limiting factor in the future, causing a shift in drivers that increase the exposure of the population to flood risk towards sea level rise. The estimated exposure to flooding shows that large numbers of people are potentially at risk (18000 in Portsea for a $1: 200$ event), but they are currently mostly protected by sea defences constructed to a present day $1: 200$ event, with a GBP 44 million defence improvement programme recently announced (Dredging Today, 2015). This paper further demonstrates that assuming a stationary system (for example, assuming the urban extent is static, that population does not change, or that sea levels do not change) is likely to lead to inaccurate estimates of flood exposure and thus flood risk.

A limitation of this work is the inherent unpredictability of future changes in population dynamics across the UK. Agent-based approaches have been used to predict development and population change (such as developed by Fontaine, 2010). Coupling the method presented in this paper with such approaches will develop insights on these processes. 
The approach developed here agrees with an independent, national scale assessment of exposure. The methodology can be applied to other areas of the UK, or elsewhere, where population, urban extent and sea level data exists. Attribution of local flood exposure and risk will depend on relative sea level and morphology/hydrology and population dynamics. National studies have shown development in flood risk areas in the UK is increasing, in some cases at a higher rate than development outside of the floodplain (ASC, 2011). Hence, exposure to coastal flooding due to socio-economic drivers seems likely to continue, following the historic trends shown here.
A combination of novel methodologies such as those developed in this paper, and continued collection of high quality data sets on floodplain geometry, sea level and population will contribute towards increased knowledge and understanding in this field. This will aid coastal managers as they prepare to face the challenges of an uncertain future. 


\section{Appendix A: Technical appendix}

\section{A1 Modelling assumptions and considerations}

The assumptions used in the methodology are summarised in Table A1. The temporal resolution of the available demographic data constrained the time step to 10 years. Whilst this time step may miss shorter term changes (i.e. seasonal/yearly variations in hydrology), it captures the longer term dynamics of population change and development, and sea level rise which occurs over a long time period. Further, the high spatial resolution and quality of the census data used gives the study greater reliability than if supplementary data (perhaps with a smaller time step) were used.

\section{A2 Population scaling method}

This data 1971-2011 exists in the form of population weighted centroid points. Each point represents a census output area and contains the total population of the output area.

For census data pre-1971 aggregate population counts for the city of Portsmouth (scaled to represent population within Portsea Island) and for Hayling Island were used. Scaling the total counts in this way deals with the problem of changing geographies through time (e.g. changing administrative boundaries). The populations were scaled using aggregate population counts for the city of Portsmouth for census years 1801-1961 and the modelled counts (spatial populations from centroid points) for census years 1971-2011 (Eq. A1).

Pop $_{\text {scaled }_{i}}=\operatorname{Pop}_{\text {total }_{i}} \times \frac{\sum_{n=1971}^{2011} \frac{n_{\text {modelled }}}{n_{\text {total }}}}{n_{\text {years }}}$,

where: Pop $_{\text {scaled }_{i}}=$ is the scaled population used within the model at time step $i$; Poptotal $_{i}=$ is the total population for Portsmouth from the census data at time step $i ; n_{\text {modelled }}=$ is the modelled population used in the spatial census study (1971-2011); $n_{\text {total }}=$ the total population for Portsmouth from the census data (1971-2011); $n_{\text {years }}=$ is the number of years where spatial data exists (which is $=5$ for the case study).

Figure 4 summarises our reconstruction of the population in Portsea and Hayling; which for the former rose from 39000 in 1841 to a peak of 194000 in 1931. The population then falls to a low of 134000 in 1981 before rising again to 164000 in 2011. The modelled populations from 1801-1961 were from scaled population counts, and 1971-2011 from spatial census data. Historic census data for Hayling parish (which covers the spatial area of Hayling Island) extend to 1801. However, it is not complete due to changing administrative boundaries during the 19th and 20th centuries. Therefore the population counts for missing census years were interpolated. The population in Hayling rose steadily from just under 600 in 1801 to 4000 in 1941. Population continued to increase at a higher rate until the maximum of 17400 in 2011. Modelled populations in 1801-1851, and 1881-1931

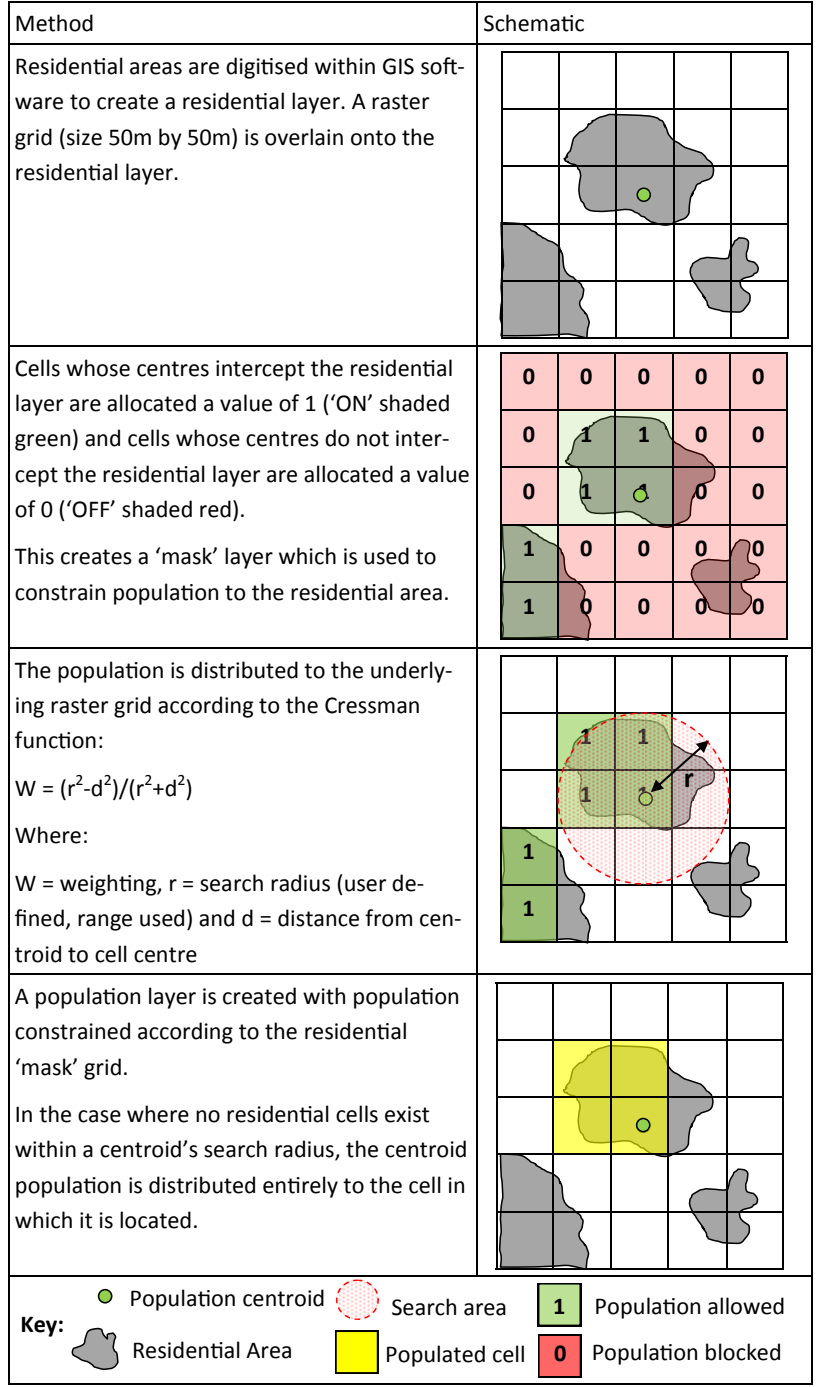

Figure A1. Population spreading method used in this study. See Martin (1989) and Bracken and Martin (1989) for further information on the centroid distribution method.

are formed from raw counts from census data, with values in 1861-1871 and 1941-1961 interpolated from these counts. Between 1971 and 2011 spatial census data for Hayling were used.

\section{A3 Residential layer method}

Maps (sourced from Digimap ${ }^{\circledR}$, University of Edinburgh) for the 1870s, 1890s, 1910s, 1930s, 1960s, 1970s, 1990s and 2012 are summarised in Table A2. Developed areas were hand-digitised to create a residential layer of where population is situated. This allowed population to be spread more realistically. Non-residential features such as schools, hospitals and industrial units (e.g. the Portsmouth Dockyard) were removed from the residential layer in order to increase the accuracy of the population spreading. Use of a residential 
layer addresses the problem of differing census geographies by constraining population to the area developed for each time step.

The time between publication of the maps used averages 20 years between 1870-2011, which is typical of spatial planning timescales and so a reasonable assumption. Assuming static development over a 70 year time period (18011871 ) is more uncertain, however the low level of development seen in 1871 does limit the effect of this assumption. Analysis from 1801 is therefore included in the analysis but with the caveat that we are less certain of the results over this time frame.

The vector residential layer was converted to a $50 \mathrm{~m}$ raster mask for compatibility with Surface Builder ${ }^{\mathrm{TM}}$. A $50 \mathrm{~m}$ resolution includes adjacent roads in residential masks. However, the spatial resolution of census data makes higher resolution (e.g. $10 \mathrm{~m}$ grid cells) unrealistic. This layer was used as a mask within SurfaceBuilder ${ }^{\mathrm{TM}}$ which prevented the program placing population into areas that should not be populated.

\section{A4 Population spreading method}

The methodology used within SurfaceBuilder ${ }^{\mathrm{TM}}$ is shown in Fig. 8. A range of search radii were used in order to account for uncertainty due to this method. The search radii limits the distance from each centroid that the population can be distributed.

\section{A5 Sources of uncertainty}

There is uncertainty inherent in the estimated sea level, and the number and spatial location of the population. The uncertainty in rate of sea level applied was quantified by modelling for three different rates; the mean change from Haigh et al. (2011) and \pm one standard deviation from this. Uncertainty in the population estimates are harder to quantify. The measured undercount in the 2001 census was calculated as $6 \%$ (ONS, 2012a). There is a smaller potential for overcount which was estimated as $2 \%$ for the 2011 Census (ONS, $2012 \mathrm{~b}$ ). These uncertainties are accounted for in census population counts, however for older censuses the adjustments may not have been performed and so as a conservative estimate we assume a potential uncertainty of +6 and $-2 \%$ in the population estimate (i.e. potential $6 \%$ undercount, $2 \%$ overcount). The spatial location of the population is sensitive to the search radii used when distributing the population from the centroid points. The uncertainty in population location was quantified by testing a variety of search radii. The relative contributions of these three sources of uncertainty are shown in Fig. A2.
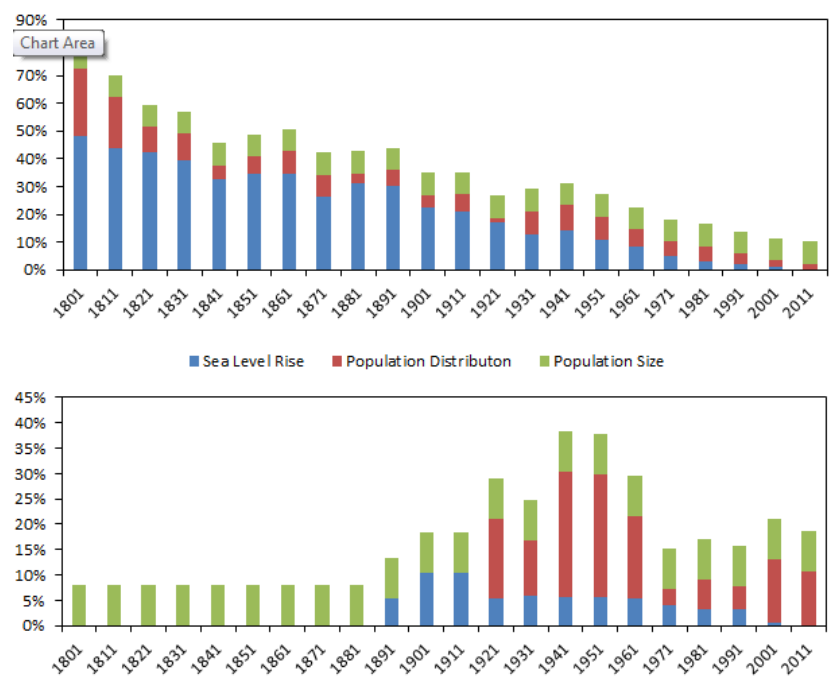

Figure A2. Quantification of the sources of uncertainty within the methodology for Portsea (above) and Hayling (below).

For Portsea, the uncertainty in sea level has a much bigger effect than Hayling as there is a much larger population density on the island, and so the floodplain size (a function of the sea level elevation) has a more pronounced effect on the estimated exposure. In Hayling there is a much smaller density of people and so the exposure is less sensitive to a slightly smaller/bigger floodplain.

In Portsea the distribution of the population has a moderate effect on exposure in the early 1800s, with an increasingly smaller effect for the more modern (better quality) census data. In Hayling there is no effect before 1920 as the low absolute exposure (less than 50 people exposed as the "best estimate") is not sensitive to changes in population distribution. As the population in Hayling started to encroach on the floodplain from 1920 onwards, the distribution has a larger relative effect.

The uncertainty as a result of population size is static through time for both Portsea and Hayling as this is assumed to be $6 \%$ for undercount and $2 \%$ for overcount (i.e. uncertainty in census data - see ONS, 2012a). 
Table A1. Modelling Assumptions and justifications.

\begin{tabular}{|c|c|c|}
\hline Component & Modelling assumption & Justification \\
\hline $\begin{array}{l}\text { Hydrodynamic model } \\
\text { (LISFLOOD FP) }\end{array}$ & $\begin{array}{l}\text { Simplified hydraulics compared to } \\
\text { "full" 2-D models } \\
\text { Sea level and extremes of still water } \\
\text { level are dominant physical drivers } \\
\text { (waves excluded) } \\
\text { See Bates et al. (2010) }\end{array}$ & $\begin{array}{l}\text { Better than "bathtub" methods (mass conservancy and } \\
\text { hydraulic connectivity accounted for) } \\
\text { Widely used flood model (e.g. Wadey et al., 2012; Daw- } \\
\text { son et al., 2009; Rojas et al., 2013) } \\
\text { Use of full models expensive (cost and computation- } \\
\text { ally) and without validation improved accuracy cannot } \\
\text { be confirmed } \\
\text { Represents realistic storm tide inflow } \\
\text { Waves, although important to flood events, are con- } \\
\text { tentious in an inundation modelling framework (hard to } \\
\text { validate) but recommended for inclusion in future work } \\
\text { Model proven for coastal use (Bates et al., 2005) and } \\
\text { with a validated model for the case study region (Wadey } \\
\text { et al., 2012). }\end{array}$ \\
\hline Residential area & $\begin{array}{l}\text { Developed residential area does not } \\
\text { change between time steps (average } 20 \\
\text { year time step - based on availability of } \\
\text { historic maps) }\end{array}$ & $\begin{array}{l}20 \text { years is typical of long-term spatial planning time } \\
\text { horizon (Zevenbergen et al., 2008). Constraining pop- } \\
\text { ulation to residential area improves spreading over uni- } \\
\text { formly distributing population, so best available method }\end{array}$ \\
\hline Population distribution & $\begin{array}{l}\text { A centroid defines a location with above } \\
\text { average population density and is a } \\
\text { summary point for the local area } \\
\text { A centroid's population is distributed in } \\
\text { the surrounding area according to some } \\
\text { distance decay function, which has fi- } \\
\text { nite extent } \\
\text { Regions may exist in the population } \\
\text { plane in which no population is present. } \\
\text { Assumptions from Martin (1989) }\end{array}$ & $\begin{array}{l}\text { Allows for high resolution population } \\
\text { surfaces (Martin, 1989) } \\
\text { Method offers stability through time and ease of inte- } \\
\text { gration with non-population data sources (Martin et al., } \\
\text { 2011); both are essential parts of the methodology dis- } \\
\text { cussed in this paper }\end{array}$ \\
\hline $\begin{array}{l}\text { Population change } \\
\text { over time }\end{array}$ & $\begin{array}{l}\text { The dates chosen represent a trend in } \\
\text { population change, rather than oscilla- } \\
\text { tions (which do not show correlation } \\
\text { over time). } \\
\text { The dates chosen are representative of } \\
\text { population change }\end{array}$ & $\begin{array}{l}\text { A period of } 200 \text { years was chosen to allow for a clear } \\
\text { trend to propagate as opposed to variation which may } \\
\text { occur over a smaller time span } \\
\text { The dates correspond to census years, where it is possi- } \\
\text { ble to get high resolution spatial population and demog- } \\
\text { raphy data. To use other years with less sufficient data } \\
\text { would limit the reliability of the study }\end{array}$ \\
\hline
\end{tabular}

Table A2. Historic maps used to create residential masks for each census year. All maps sourced from Digimap ${ }^{\circledR}$ Crown Copyright and Landmark Information Group Limited (2014). All rights reserved.

\begin{tabular}{ll}
\hline Census year & Map used to create residential layer \\
\hline $1801-1871$ & County Series Edition 1 (1870s) \\
$1881-1891$ & County Series Revision 1 (1890s) \\
$1901-1911$ & County Series Revision 2 (1910s) \\
$1921-1931$ & County Series Revision 3 (1930s) \\
$1941-1961$ & National Grid Imperial Edition 1 (1960s) \\
1971 & National Grid Metric Edition 1 (1970s) \\
$1981-1991$ & Latest National Grid (1990s) \\
$2001-2011$ & MasterMap ${ }^{\circledR}(2012)$ \\
\hline
\end{tabular}


Acknowledgements. Andrew Stevens acknowledges a University of Southampton studentship from the EPSRC (Engineering and Physical Sciences Research Council). Thanks is extended to the University of Edinburgh's Digimap ${ }^{\circledR}$ team for their extensive work digitising census data which made this study possible. ESRI's ArcGIS was the GIS tool used.

Edited by: J. Brown

\section{References}

ASC: Adapting to climate change in the UK Measuring progress: Adaptation Sub-Committee Progress Report 2011, London, UK, 2011.

Bates, P. D., Dawson, R. J., Hall, J. W., Matthew, S. H. F., Nicholls, R. J., Wicks, J., and Hassan, M.: Simplified two-dimensional numerical modelling of coastal flooding and example applications, Coast. Eng., 52, 793-810, 2005.

Bates, P. D., Horritt, M. S., and Fewtrell, T. J.: A simple inertial formulation of the shallow water equations for efficient twodimensional flood inundation modelling, J. Hydrol., 387, 33-45, 2010.

Batstone, C., Lawless, M., Tawn, J., Horsburgh, K., Blackman, D., McMillan, A., Worth, D., Laeger, S., and Hunt, T.: A UK bestpractice approach for extreme sea-level analysis along complex topographic coastlines, Ocean Eng., 71, 28-39, 2013.

Blaikie, P., Cannon, T., Davis, I., and Wisner, B.: At risk: natural hazards, peoples vulnerability and disasters, Routledge, London, UK, 1994.

Bracken, I. and Martin, D.: The Generation of Spatial Populationdistribution from Census Centroid Data, Environ. Plann. A, 21, 537-543, 1989.

Chini, N. and Stansby, P. K.: Extreme values of coastal wave overtopping accounting for climate change and sea level rise, Coast. Eng., 65, 27-37, 2012.

Church, J. A., Clark, P. U., Cazenave, A., Gregory, J. M., Jevrejeva, S., Levermann, A., Merrifield, M. A., Milne, G. A., Nerem, R. S., Nunn, P. D., Payne, A. J., Pfeffer, W. T., Stammer, D., and Unnikrishnan, A. S.: Sea Level Change, in: Climate Change 2013: The Physical Science Basis. Contribution of Working Group I to the Fifth Assessment Report of the Intergovernmental Panel on Climate Change, edited by: Stocker, T. F., Qin, D., Plattner, G.K., Tignor, M., Allen, S. K., Boschung, J., Nauels, A., Xia, Y., Bex, V., and Midgley, P. M., Cambridge, United Kingdom and New York, NY, USA, Cambridge University Press, 2013.

Dawson, R. J., Dickson, M. E., Nicholls, R. J., Hall, J. W., Walkden, M. J. A., Stansby, P. K., Mokrech, M., Richards, J., Zhou, J., Milligan, J., Jordan, A., Pearson, S., Rees, J., Bates, P. D., Koukoulas, S., and Watkinson, A. R.: Integrated analysis of risks of coastal flooding and cliff erosion under scenarios of long term change, Climatic Change, 95, 249-288, 2009.

Dawson, R. J., Peppe, R., and Wang, M.: An agent-based model for risk-based flood incident management, Natural Hazards, 59, 167-189, 2011.

Dredging Today: Portsmouth Coastal Scheme About to Begin [Online], available at: http://www.dredgingtoday.com/2015/ 01/30/portsmouth-coastal-scheme-about-to-begin/ (last access: May 2015), 2015.
Evans, E., Ashley, R., Hall, J., Penning-Rowsell, E., Saul, A., Sayers, P., Thorne, C., and Watkinson, A.: Foresight. Future Flooding, Scientific Summary: Volume I - Future risks and their drivers, London, UK, 2004.

Fielding, J.: Environmental injustice or just the lie of the land: an investigation of the socio-economic class of those at risk from flooding in England and Wales, Sociological Research Online, 12, 36 pp., 2007.

Fontaine, C. M.: Residential Agents \& Land Use Change Modelling, PhD thesis, University of Edinburgh, 2010.

Gouldby, B., Sayers, P., Mulet-Marti, J., Hassan, M., and Benwell, D.: A methodology for regional-scale flood risk assessment, Proceedings of the Institution of Civil Engineers - Water Management, 161, 169-182, 2008.

Gwilliam, J., Fedeski, M., Lindley, S., Theuray, N., and Handley, J.: Methods for assessing risk from climate hazards in urban areas, Proceedings of the Institution of Civil Engineers-Municipal Engineer, 159, 245-255, 2006.

Haigh, I. D., Nicholls, R., and Wells, N.: A comparison of the main methods for estimating probabilities of extreme still water levels, Coast. Eng., 57, 838-849, 2010.

Haigh, I. D., Nicholls, R. J., and Wells, N.: Rising sea levels in the English Channel 1900 to 2100, Proceedings of the Institution of Civil Engineers-Maritime Engineering, 164, 2011.

Hampshire County Council: A demographic profile of Portsmouth's past 1801-2001, 2001.

Holdgate, M. W.: A perspective of environmental pollution, Cambridge, UK: Cambridge University Press, 1979.

IPCC: Summary for Policymakers, in: Climate Change 2013: The Physical Science Basis. Contribution of Working Group I to the Fifth Assessment Report of the Intergovernmental Panel on Climate Change, edited by: Stocker, T. F., Qin, D., Plattner, G.-K., Tignor, M., Allen, S. K., Boschung, J., Nauels, A., Xia, Y., Bex, V., and Midgley, P. M., Cambridge, UK and New York, NY, USA: Cambridge University Press, 2013.

Jonkman, S. N., Vrijling, J. K., and Vrouwenvelder, A. C. W. M.: Methods for the estimation of loss of life due to floods: a literature review and a proposal for a new method, Natural Hazards, 46, 353-389, 2008.

Kron, W.: Flood Risk = Hazard Values Vulnerability, Water Int., 30, 58-68, 2005.

Kron, W.: Coasts, the Riskiest Place on Earth, edited by: Mckee Smith, J., Proceedings of the 31st International Conference of Coastal Engineering, 3-21, 2008.

Langford, M.: Rapid facilitation of dasymetric-based population interpolation by means of raster pixel maps, Comput. Environ. Urban, 31, 19-18, 2007.

Lichter, M., Vafeidis, A. T., Nicholls, R. J., and Kaiser, G.: Exploring Data-Related Uncertainties in Analyses of Land Area and Population in the "Low-Elevation Coastal Zone" (LECZ), J. Coastal Res., 274, 757-768, 2011.

Martin, D.: Mapping Population Data from Zone Centroid Locations, Transactions of the Institute of British Geographers NS, 14, 90-97, 1989.

Martin, D., Dorling, D., and Mitchell, R.: Linking censuses through time: problems and solutions, Area, 34, 82-91, 2002.

Martin, D., Lloyd, C., and Shuttleworth, I.: Evaluation of gridded population models using 2001 Northern Ireland Census data, Environ. Plann. A, 43, 1965-1980, 2011. 
Narayan, S., Nicholls, R. J., Clarke, D., Hanson, S., Reeve, D., Horrillo-Caraballo, J., le Cozannet, G., Hissel, F., Kowalska, B., and Parda, R.: The SPR systems model as a conceptual foundation for rapid integrated risk appraisals: Lessons from Europe, Coast. Eng., 87, 15-31, 2014.

NFDC (New Forest District Council): North Solent Shoreline Management Plan, available at: www.northsolentsmp.co.uk (last access: May 2015), 2010.

NFF: At risk of flooding?, National Flood Forum, available at: http://www.nationalfloodforum.org.uk/at-risk-of-flooding-2/ (last access: May 2015), 2015.

Nicholls, R. J.: Coastal megacities and climate change, GeoJournal, 37, 369-379, 1995.

Nicholls, R. J.: Impacts of and responses to sea-level rise, in: Understanding Sea-Level Rise and Variability, edited by: Church, J. A., Woodworth, P. L., Aarup, T., and Wilson, W. W., WileyBlackwell, 2010.

Office of Population Censuses and Surveys: 1981 Census: Aggregate data (England and Wales) [computer file], available at: http://digimap.edina.ac.uk/ (last access: May 2015), 1981.

Office of Population Censuses and Surveys: 1991 Census: Aggregate data (England and Wales) [computer file], available at: http://digimap.edina.ac.uk/ (last access: May 2015), 1991.

ONS: 2001 Census: Aggregate data (England and Wales) [computer file], available at: http://digimap.edina.ac.uk/ (last access: May 2015), 2001.

ONS: 2011 Census: Aggregate data (England and Wales) [computer file], available at: http://digimap.edina.ac.uk/ (last access: May 2015), 2011.

ONS: The 2011 Census Coverage Assessment and Adjustment Process, 2011 Census: Methods and Quality Report, available at: http://www.ons.gov.uk/ons/guide-method/ census/2011/census-data/2011-census-data/2011-first-release/ first-release--quality-assurance-and-methodology-papers/ coverage-assessment-and-adjustment-process.pdf (last access: May 2015), 2012a.

ONS: Overcount Estimation and Adjustment. 2011 Census: Methods and Quality Report, available at: http://www.ons.gov.uk/ons/guide-method/census/ 2011/census-data/2011-census-data/2011-first-release/ first-release--quality-assurance-and-methodology-papers/ overcount-estimation-and-adjustment.pdf (last access: May 2015), 2012b.

Penning-Rowsell, E., Johnson, C., Tunstall, S., Tapsell, S., Morris, J., Chatterton, J., and Green, C.: The Benefits of Flood and Coastal Risk Management: A Handbook of Assessment Techniques, London, UK, 2005.

Penning-Rowsell, E., Priest, S., Parker, D., Morris, J., Tunstall, S., Viavattene, C., Chatterton, J., and Owen, D.: Flood and Coastal Erosion Risk Management. A Manual for Economic Appraisal, Routledge, London, UK and New York, NY, USA, 2013.

Quinn, N., Lewis, M., Wadey, M., and Haigh, I.: Assessing the temporal variability in extreme storm-tide time series for coastal flood risk assessment, J. Geophys. Res.-Oceans, 119, 49834998, 2014.
Registrar General for England and Wales: 1971 Census: Aggregate data (Great Britain) [computer file], Digitised Census data, available at: http://digimap.edina.ac.uk/ (last access: May 2015), 1971.

RIBA and ICE: Facing up to rising sea-levels: retreat? defend? attack? The future of our coastal and estuarine cities, available at: www.buildingfutures.org.uk (last access: May 2015), 2008.

Rojas, R., Feyen, L., and Watkiss, P.: Climate change and river floods in the European Union: Socio-economic consequences and the costs and benefits of adaptation, Global Environ. Chang., 23, 1737-1751, 2013.

Ruocco, A. C., Nicholls, R. J., Haigh, I. D., and Wadey, M. P.: Reconstructing coastal flood occurrence combining sea level and media sources: a case study of the Solent, UK since 1935, Natural Hazards, 59, 1773-1796, 2011.

Samuels, P. and Gouldby, B.: Language of Risk Project Definitions, 2nd Edn., FLOODsite Consortium, available at: http://www.floodsite.net/html/partner_area/project_docs/T32_ 04_01_FLOODsite_Language_of_Risk_D32_2_v5_2_P1.pdf (last access: May 2015), 2009.

Sayers, P., Hall, J., Rosu, C., Chatterton, J., and Deakin, R.: Risk assessment of flood and coastal defences for strategic planning (RASP) - a high level methodology, Environment Agency, London, UK, 2002.

Small, C. and Nicholls, R. J.: A Global Analysis of Human Settlement in Coastal Zones, Coastal Research, 19, 584-599, 2003.

Smith, A. M.: Modelling the Impacts of a Changing Climate on Flood Risk, PhD Thesis, University of Bristol: UK, 2015.

Smith, R. A. E., Bates, P. D., and Hayes, C.: Evaluation of a coastal flood inundation model using hard and soft data, Environ. Model. Softw., 30, 35-46, 2012.

Thrush, D., Burningham, K., Fielding, J., and Agency, E.: Flood Warning for Vulnerable Groups: Measuring \& Mapping Vulnerability R\&D Technical Report W5C-018/4, Bristol, UK, 2005.

UNDRO: Shelter after Disaster: Guidelines for Assistance, Geneva, Switzerland, 1982.

United Nations and Birkmann, J.: Measuring Vulnerability to Natural Hazards: Towards Disaster Resilient Societies, United Nations University Press, New York, NY, USA, 2006.

USACE, The Japanese Ministry of Land Infrastructure Transport and Tourism, Environment Agency \& Rijkswaterstaat: Flood Risk Management Approaches As being practiced in Japan, Netherlands, United Kingdom, and United States, 2011.

Wadey, M. P., Nicholls, R. J., Hutton, C.: Coastal Flooding in the Solent: An Integrated Analysis of Defences and Inundation, Water, 4, 430-459, 2012.

Wadey, M. P., Nicholls, R. J., and Haigh, I.: Understanding a coastal flood event: the 10th March 2008 storm surge event in the Solent, UK, Natural Hazards, 67, 829-854, 2013.

Wadey, M. P., Cope, S. N., Nicholls, R. J., Mchugh, K., Grewcock, G., and Mason, T.: Extreme Sea Levels and Flood Events in a Coastal Town: Community Participatory Exercise and Inundation Analysis, Environ. Model. Softw., 31, 1-22, 2015.

Wahl, T., Haigh, I. D., Woodworth, P. L., Albrecht, F., Dillingh, D., Jensen, J., Nicholls, R. J., Weisse, R., and Wöppelmann, G.: Observed mean sea level changes around the North Sea coastline from 1800 to present, Earth-Sci. Rev., 124, 51-67, 2013. 
Wallingford, H. R.: Flood Hazard Research Centre \& Risk and Policy Analysts Ltd., 2006, R\&D Outputs: Flood Risk to People (Phase 2 Report), London, UK, 2006.

Wolf, J., Brown, J. M., and Howarth, M. J.: The wave climate of Liverpool Bay - observations and modelling, Ocean Dynam., 61, 639-655, 2011.
Zevenbergen, C., Veerbeek, W., Gersonius, B., Thepen, J., and van Herk, S.: Adapting to climate change: using urban renewal in managing long-term flood risk, Flood Recovery, Innovation and Response, 118, 221-233, 2008. 